Felix W.H. Chan*, Wai-Sum Chan and Johnny S.H. Li

\title{
Assessing Personal Injury Liabilities in China from National to Provincial Level: An International Comparative Analysis
}

DOI 10.1515/ajle-2016-0015

\begin{abstract}
In a tort-based legal system, when a party is injured as a consequence of another party's negligence, the party should be provided with sufficient compensation so that he or she may live as fulfilling a life as possible after the injury. The moral objective underlying this supposition is intuitively appealing. It is not surprising, therefore, that this jurisprudential notion is favourably regarded and widely applied in various common law and civilian jurisdictions, despite differences in tradition and culture. Nonetheless, although the two bodies of law share a similar objective in this respect, there are a number of differences in the substantive content of the law and the configuration of the rules. The present authors argue, and provide empirical evidence to support, that there are signs of convergence as both legal systems are in fact applying the same multiplicand-multiplier approach in assessing the quantum of damages. Case studies in mainland China (concerning civil law) and in the United Kingdom and Hong Kong (regarding common law) are adopted as the research methodology to explore the broader implications of this convergence.
\end{abstract}

Keywords: actuarial evidence; multiplier-multiplicand approach; personal injury; quantum of damages; tort.

\section{Introduction}

Although the Hong Kong Special Administrative Region is a part of China, the legal systems in Hong Kong and the People's Republic of China (PRC) are fundamentally different. Under the principle of "one country, two systems” prescribed

\footnotetext{
*Corresponding author: Felix W.H. Chan, Faculty of Law, University of Hong Kong, Hong Kong, People's Republic of China, e-mail: fwhchan@hku.hk

Wai-Sum Chan: School of Business, Chinese University of Hong Kong, Hong Kong, People's Republic of China

Johnny S.H. Li: Fairfax Chair in Risk Management, Department of Statistics and Actuarial Science, University of Waterloo, Waterloo, Ontario, Canada
} 
by the Hong Kong Basic Law, ${ }^{1}$ Hong Kong retained its common law system ${ }^{2}$ following the change of sovereignty in July 1997. Although the common law system in Hong Kong is remarkably different from the civil law system in the PRC, the two legal systems share a similar ideological basis concerning the assessment of damages in personal injury litigations. When a party is injured in a tort-based legal system as a consequence of another party's negligence, that party should be provided with sufficient compensation so that he or she may continue to live as fulfilling a life as possible. The basic principle underlying the assessment of the quantum of damages is restitutio in integrum. This principle has been defined in various dicta of the English courts. For example, Lord Blackburn stated:

Where any injury is to be compensated by damages, in settling the sum of money to be given ... you should as nearly as possible get at that sum of money which will put the person who has been injured ... in the same position as he would have been in if he had not sustained the wrong. ${ }^{3}$

In the PRC, Article 16 of the Tort Liability Law ${ }^{4}$ states:

Where a tort causes any personal injury to another person, the tortfeasor shall compensate the victim for the reasonable costs and expenses for treatment and rehabilitation, such as medical treatment expenses, nursing fees, travel expenses and lost wages. If the victim suffers any disability, the tortfeasor shall also pay the costs of disability assistance equipment for the living of the victim and the disability indemnity. If it causes the death of the victim, the tortfeasor shall also pay the funeral service fees and the death compensation.

Tort law is private law upholding personal rights and providing remedies for breaches of obligations between wrongdoers and victims. Nonetheless, it often illuminates the relationship between the public and private dimensions of private law. It is of private significance that the victims receive adequate damages to recompense them for the wrong they have suffered. It is also of public significance to engender trust in the judicial system that assesses and grants such compensation. This requires that the system of compensation be objectively benchmarked against sensible economic criteria.

1 The Basic Law of the Hong Kong Special Administrative Region of the PRC. (Adopted at the third session of the seventh National People's Congress on 4 April 1990 and promulgated by Order No. 26 of the President of the PRC on 4 April 1990, which became effective as of 1 July 1997.). 2 Hong Kong Basic Law Article 8: "The laws previously in force in Hong Kong, that is, the common law, rules of equity, ordinances, subordinate legislation and customary law shall be maintained ...."

3 Livingstone v Rawyards Coal Co. (1880) 5 App Cas 25 (HL), 39.

4 The PRC Tort Liability Law (2010). 
In Hong Kong and the PRC, there are both similarities and differences in the way this ideological belief is put into judicial practise. When assessing future pecuniary loss in personal injury litigations, both legal systems often use the multiplicand-multiplier approach. The objective is to calculate a lump sum to compensate the plaintiff for future loss of earnings, the loss of pension rights and to cover future expenses. One of the earliest awards of lump-sum compensation was found in ancient Anglo-Saxon law, which was variously called wergild, or bøde (which means "man payment” in old English). It was a legal device for determining the quantum of damages payable by the wrongdoers to the injured parties, or in case of fatal accidents, to the victims' family members. ${ }^{5}$ In different judicial systems across ancient Europe, the amount of wergild was often decided on the basis of a victim's gender and social status. Although some scholars argued that the amounts of wergild were set arbitrarily, subsequent findings based on historical evidence support the argument that the assessment of wergild was actually based on an estimate of the victim's "value." Without doubt, there were flaws in the methodology used to determine the wergild from the contemporary economic and actuarial perspectives. Nonetheless, the notion of wergild sheds light on the historical background of the assessment of the value of a human life in the context of calculating compensation for personal injury and wrongful death.

Modern English law applies cross-disciplinary principles, such as economic value and actuarial expectation, to assess the quantum of compensation. To consider how future losses could accurately be computed for the purpose of providing full compensation, the House of Lords in Wells $v$ Wells ${ }^{7}$ ruled that detailed actuarial advice and economic evidence should be considered. This has become standard practise in many common law jurisdictions, including Hong Kong. As mentioned, when assessing future pecuniary loss in personal injury claims, the multiplicand-multiplier approach is often applied under English common law. The goal is to calculate a lump-sum amount to compensate the plaintiff for future loss of earnings, and to cover future care and medical expenses. The "multiplicand" (e.g. the annual loss of income or the annual costs of care) is established by evidence put before the judge, who then has to decide an appropriate multiplier. The "multiplier" is used to discount the future pecuniary values to a present-day lump sum amount.

5 Frederick Pollock and Frederick Maitland, English Law before the Time of Edward First (CUP 1899), 460.

6 A. Hofflander, "The Human Life Value: An Historical Perspective," Journal of Risk and Insurance 381, (1966), 33.

7 [1999] 1 AC 345 (HL). 
In the PRC, for many years, the multiplier figures were immensely difficult to determine on any scientific basis due to insufficient interdisciplinary research in law, economics and actuarial mathematics. Determination of the multiplicand in the PRC system heavily depends on the geographical residence of the victim, which frequently generates heated public debates regarding the fairness of such judicial practise. $^{8}$

Apart from claiming general damages for pain, suffering and loss of amenity, a victim is also entitled to plead economic losses suffered as a consequence of the accident. There are many categories of direct losses, such as future income that the injured would have earned but for the accident, and expenses that would not have otherwise been incurred but for the accident. This paper focuses on the lump-sum compensation of pecuniary loss for life. Through comparative analysis of the case law from Hong Kong and the United Kingdom (UK) and the judicial application of the statute law of the PRC, the present authors argue that there are signs of convergence. Both legal systems are in fact applying the same multiplicand-multiplier approach in assessing the quantum of damages. The broader implications of this convergence are examined in this article.

\section{The Civil Law Approach in the PRC}

\subsection{The Current Position in the PRC}

The General Principles of the Civil Law (GPCL) is a cornerstone of modern civil law (as opposed to criminal law) in the PRC. The GPCL was first promulgated in 1986, and comprises 9 chapters and 156 articles. A number of provisions in the GPCL were amended in 2009.9 The following provisions are relevant to personal injury compensation:

- Article 98. Citizens shall enjoy the rights of life and health.

- Article 106. Citizens and legal persons who breach a contract or fail to fulfil other obligations shall bear civil liability.

- Article 119. Anyone who infringes upon a citizen's person and causes him physical injury shall pay his medical expenses and his loss in income due to missed working time and shall pay him living subsidies if he is disabled; if the victim dies, the infringer shall also pay the funeral expenses, the necessary living expenses of the deceased's dependents and other such expenses.

8 Chunyan Ding, Medical Negligence Law in Transitional China (Intersentia, 2012), 218-34.

9 Decision of the Standing Committee of the National People's Congress on Amending Some Laws Order no. 18 (2009). 
In addition to the GPCL, there are several legislations and judicial documents ${ }^{10}$ related to the assessment of personal injury damages in the PRC. The rapid social and economic changes in the PRC over the past decades have prompted significant changes in personal injury litigation, both in terms of quantity and diversity. Such changes have generated many unprecedented problems and unforeseen circumstances that were probably not anticipated by the original drafters of GPCL and the relevant legislation. Fortunately, the issuance of Judicial Interpretation No. $20^{11}$ in May 2004 ("Judicial Interpretation") provided long-awaited clarification. In particular, Article 29 of the Judicial Interpretation specifies the methodology for computing the lump-sum award for loss of future income for life:

Lump-Sum Award = Loss of Annual Income $\times$ Statutory Annuity Factor.

This formula resembles that of the multiplicand-multiplier approach adopted in most common law jurisdictions, where the multiplicand represents the loss of yearly income and the multiplier is deduced from a statutory annuity factor.

In the PRC, each person has a hukou (household registration) that classifies them as "rural" or "urban," in a fixed provincial-level region. ${ }^{12}$ The item "Loss of Annual Income” (LAI) depends on the claimants' geographical residence status as determined by their hukou. Article 35 of Interpretation No. 20 stipulates that the LAI should be determined according to the statistical data of the previous year at the provincial or regional level (including provinces, autonomous regions, municipality directly under the central government, special economic zones and cities under direct state planning). ${ }^{13}$ All of the data must be centrally and officially promulgated by the National Bureau of Statistics of China. ${ }^{14}$ In the context of the PRC court proceedings, data from the "previous year" means data from the statistical year (adopted by the National Bureau of Statistics of China) prior to the end of the trial at the first instance. Within the provincial or regional

10 The PRC Tort Liability Law (2010); Interpretation of the Supreme People's Court of Issues concerning the Application of Law in the Trial of Cases on Personal Injury Compensation (2004); Law of the PRC on Road Traffic Safety (2007 Amended Edition); Law of the PRC on State Compensation (1995); Measures for the Handling of Student Injury Accidents (2002); and Regulation on Handling Medical Malpractices (2002).

11 Interpretation of the Supreme People's Court of Issues concerning the Application of Law in the Trial of Cases on Personal Injury Compensation (Interpretation No. 20, 2004).

12 Regulations of the PRC on Household Registration (1958).

13 There are currently 31 regions: Beijing, Tianjin, Hebei, Shanxi, Inner Mongolia, Liaoning, Jilin, Heilongjiang, Shanghai, Jiangsu, Zhejiang, Anhui, Fujian, Jiangxi, Shandong, Henan, Hubei, Hunan, Guangdong, Guangxi, Hainan, Chongqing, Sichuan, Guizhou, Yunnan, Tibet, Shaanxi, Gansu, Qinghai, Ningxia, and Xinjiang.

$14<$ http://www.stats.gov.cn/english/> accessed 15 October 2015. 
level, the amount of LAI is either the "per capita disposable income of the urban residents" or the "per capita net income of the rural residents" in the previous year, depending on the geographical residence of a claimant. Table 1 shows the 2014 LAI amounts. For ease of reference, the figures are expressed in UD dollars (USD) per annum.

Table 1: The 2014 Loss of Annual Income (LAI) Statistics (in USD per Annum).

\begin{tabular}{|c|c|c|}
\hline Region & Urban & Rural \\
\hline Beijing & 6203 & 2821 \\
\hline Tianjin & 4968 & 2437 \\
\hline Hebei & 3474 & 1400 \\
\hline Shanxi & 3455 & 1101 \\
\hline Inner Mongolia & 3923 & 1322 \\
\hline Liaoning & 3935 & 1619 \\
\hline Jilin & 3427 & 1480 \\
\hline Heilongjiang & 3015 & 1482 \\
\hline Shanghai & 6746 & 3015 \\
\hline Jiangsu & 5006 & 2092 \\
\hline Zhejiang & 5823 & 2478 \\
\hline Anhui & 3556 & 1246 \\
\hline Fujian & 4741 & 1721 \\
\hline Jiangxi & 3365 & 1351 \\
\hline Shandong & 4348 & 1634 \\
\hline Henan & 3446 & 1304 \\
\hline Hubei & 3524 & 1364 \\
\hline Hunan & 3602 & 1288 \\
\hline Guangdong & 5091 & 1795 \\
\hline Guangxi & 3586 & 1045 \\
\hline Hainan & 3528 & 1283 \\
\hline Chongqing & 3879 & 1282 \\
\hline Sichuan & 3441 & 1215 \\
\hline Guizhou & 3180 & 836 \\
\hline Yunnan & 3575 & 945 \\
\hline Tibet & 3081 & 1012 \\
\hline Shaanxi & 3517 & 1000 \\
\hline Gansu & 2918 & 786 \\
\hline Qinghai & 3000 & 953 \\
\hline Ningxia & 3359 & 1066 \\
\hline Xinjiang & 3058 & 1123 \\
\hline National total & 4147 & 1369 \\
\hline
\end{tabular}

The official data are expressed in the PRC currency (RMB). For ease of reference in this paper, the values have all been converted from RMB to US dollars (USD), using this average exchange rate: 1 USD $=6.500$ RMB. 
The Statutory Annuity Factor (SAF) is defined in Article 29 of the Judicial Interpretation, ${ }^{15}$ and the factors are listed in Table 2 below. Unlike the determination of LAI, which relates to the geographical residence and the urban/rural status of the claimant, the SAF is solely dependent on the age of the claimant.

To illustrate the application of the multiplicand-multiplier approach in the PRC in computing the loss of future earnings (from the trial date to the presumed age of retirement), three hypothetical examples are given below.

1. A 25-year-old claimant, with a hukou in the rural region of Gansu, would receive a lump-sum award assessed as

$$
\mathrm{LAI} \times \mathrm{SAF}=786 \times 20=\$ 15,720(\mathrm{USD}) .
$$

2. A 63-year-old claimant, with a hukou in the urban region of Shanghai, would receive a lump-sum award calculated as

$$
\mathrm{LAI} \times \mathrm{SAF}=6746 \times 17=\$ 114,682(\mathrm{USD}) .
$$

3. An 80-year old claimant (a retired peasant), with a hukou in the rural region of Beijing, would receive a lump-sum compensation assessed as

$$
\mathrm{LAI} \times \mathrm{SAF}=2821 \times 5=\$ 14,105(\mathrm{USD}) .
$$

\subsection{Pitfalls in the Current PRC System}

The obvious disadvantage of the current method of assessing personal injury damages in the PRC is that there is little, if any, actuarial and economic evidence to justify the LAI and SAF figures, despite the adoption of the multiplicand-multiplier approach.

Figure 1 shows the annual per capita disposal income for urban residents versus the life expectancy at birth for each of the 31 regions of the PRC in 2013.

Table 2: The Statutory Annuity Factor (SAF) as defined in the Judicial Interpretation.

\begin{tabular}{ll}
\hline Age of the claimant & SAF \\
\hline 60 or below & 20 \\
$61-74$ & Age 61: SAF 19 \\
& Age 62: SAF 18 \\
& $\vdots \vdots \vdots$ \\
& Age 73: SAF 7 \\
& Age 74: SAF 6 \\
75 or above & 5 \\
\hline
\end{tabular}

$15 \mathrm{n} 11$. 


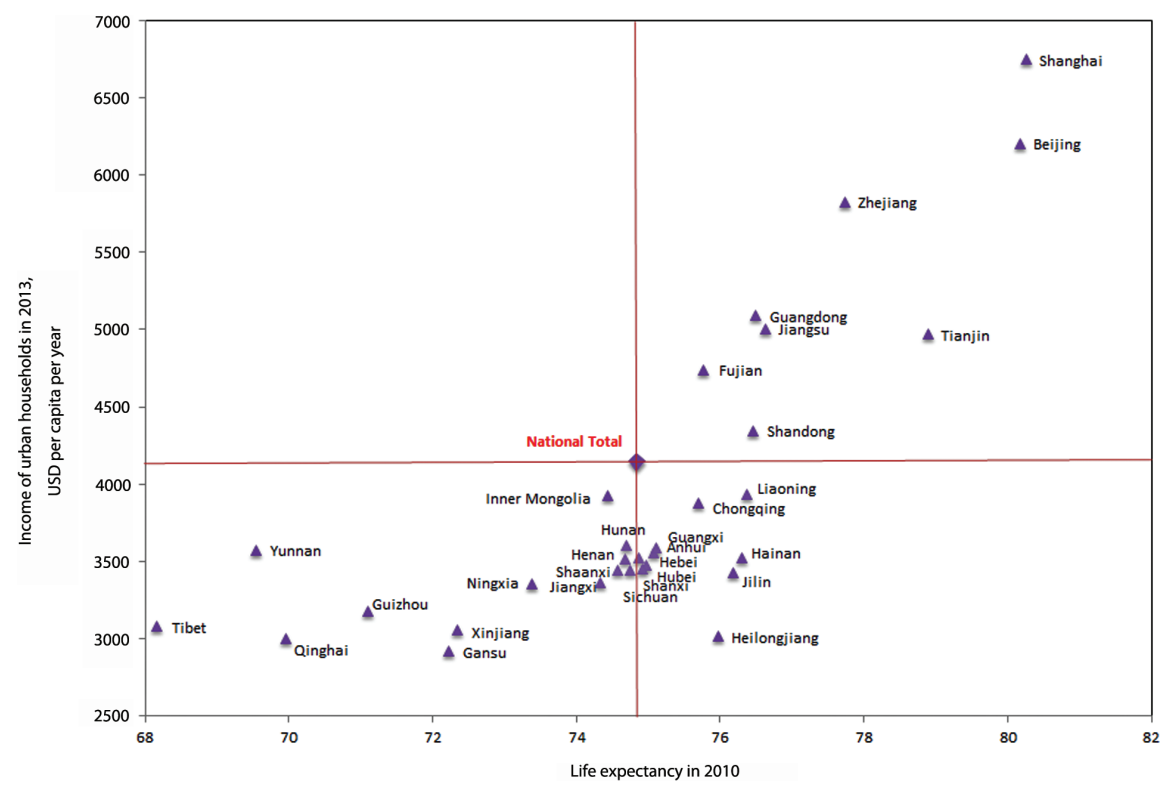

Figure 1: Annual Disposal Income (in USD) versus Life Expectancy (in years) for Regions of the PRC, 2013 (Source: China Statistical Year Book, 2014).

It can be seen that discrepancies among different regions, in terms of longevity patterns and incomes, are highly significant. The most drastic difference in life expectancies between regions is more than 12 years, while the LAI in the highestincome region is more than double that of the lowest-income province. Therefore, it appears that the current method for calculating LAI and SAF may lead to legitimate concerns regarding the doctrines of justice and equality before the law.

Furthermore, under the Judicial Interpretation, the LAI is determined by the claimant's urban or rural status as registered in the hukou. An individual's hukou is inherited from his parents at birth, and therefore it is almost impossible to change it, especially from a rural to an urban hukou. The legislative intention of the Household Registration (hukou) Law, ${ }^{16}$ which was promulgated in 1958, was to control population mobility to facilitate the PRC's central communist planning. It was effective up to the early 1990s. According to the 1982 PRC Population Census, the number of citizens who left their hukou registration place for more than 1 year was around 6.4 million, amounting to only 0.63 per cent of the total population of the PRC at that time. ${ }^{17}$ However, when the PRC's open-door policy and economic

$16 \mathrm{n} 12$.

17 China Population Statistics Yearbook (1983). 
reform reached full swing in mid-1990s, the mass movement of rural workers to cities and better developed regions (such as Shanghai, Beijing, Zhejiang and Guangdong) became a primary national strategy. "Rural migrant workers" (nongmingong), who are still registered as rural residents but are actually working and living in urban areas, form a substantial population in many major cities. It is projected that the number of rural migrant workers in urban areas will have risen from a mere 2 million in the early 1980 s to 300 million in $2015 .^{18}$

As illustrated in the above analysis, the amounts of compensation for urban and rural claimants are remarkably different. Figure 2 shows the LAI (national averages) for urban and rural residents as defined in Interpretation No. 20. The gap between urban and rural claimants is widening rapidly, and is generating serious urban-rural discrimination in personal injury litigation in the PRC. ${ }^{19}$

The urban-rural discrimination attracted wide attention in a tort case in Chongqing, ${ }^{20}$ a major city in Southwest China. Three teenage girls were killed together in a traffic accident in 2005. The three girls had many similarities in

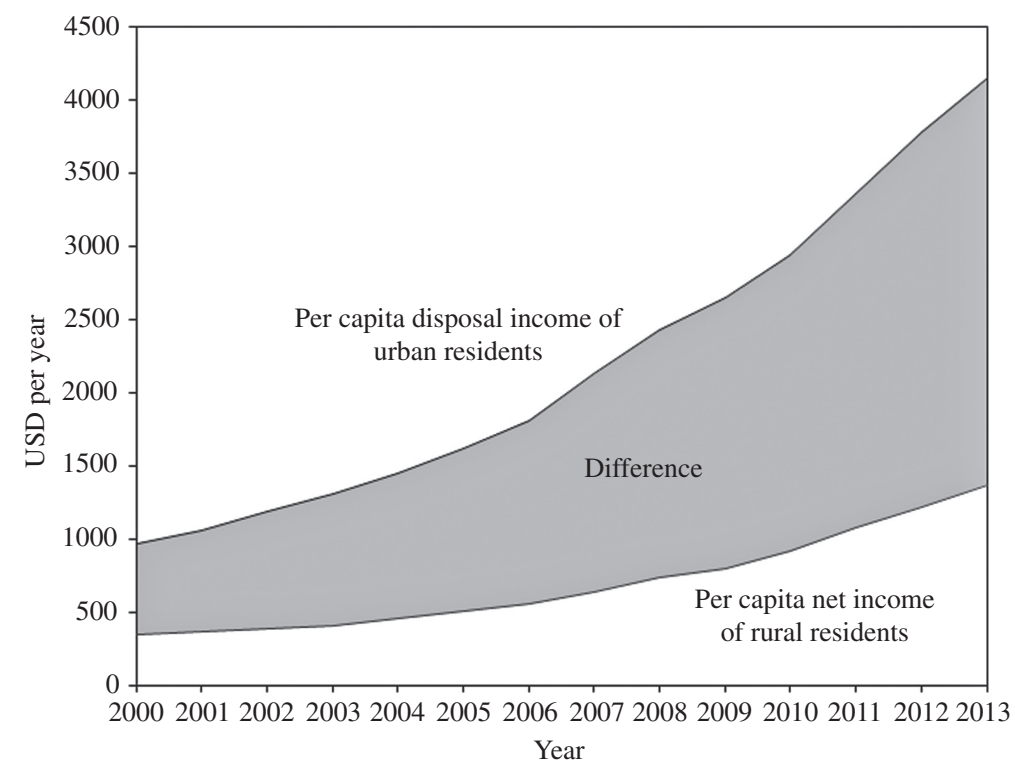

Figure 2: Annual Income of Urban and Rural Residents in the PRC, 2000-2013 (Source: China Statistical Abstract, 2014).

18 Jason Young, China's Hukou System: Markets, Migrants and Institutional Change (Palgrave MacMillan, 2013), 57.

$19 \mathrm{n} 8,218-234$.

20 n 8, 218-219. 
their backgrounds. They were living in the same neighbourhood and were classmates in the same secondary school. However, one of the girls was registered as a rural resident in her hukou, while the other two girls were registered as urban residents. The court, strictly applying the LAI definition laid down in the Judicial Interpretation, granted the families of the two urban-hukou victims more than RMB 200,000 (US\$30,770) each in damages, but the family of the rural-hukou victim only received RMB58,000 (US\$8920) in compensation. The outright discriminatory approach against the family of the victim with a rural hukou was widely reported in the public media, and precipitated a national outcry throughout China. The family of the rural victim filed an appeal in 2007 , but the appeal was dismissed by the Court of Appeal of Chongqing.

In response to the tension between the judiciary and society generated by the Chongqing case, several PRC provincial high courts issued local judicial guidelines, permitting a more flexible interpretation of the residence status (urban versus rural) of claimants in personal injury claims. ${ }^{21}$ Despite differences among provinces and regions, the guidelines recommend that rural-hukou residents who have already left their original registered locations, and have been continuously working, studying or living in the urban areas for a period of time before the trial is held, may be considered as having urban status for the purpose of determining the LAI. ${ }^{22}$

In 2009, the Standing Committee of the National People's Congress promulgated the PRC Tort Liability Law. ${ }^{23}$ Article 17 states that where the same tort causes the death of several persons, a uniform approach may be adopted in assessing the compensation payable to the victims' families. It seems obvious that this provision was introduced to directly address the public concerns that courts should not value human lives in a discriminatory manner, which was perceived to be the approach adopted by the judges in the Chongqing case. Nonetheless, the wording used in Article 17 is both ambiguous and limited in scope. It may not provide the best solution to the problems caused by the urban-rural discrimination in a variety of circumstances. For instance, Article 17 is only applicable to victims who all die in the same incident, rather than any tortious incident occurring in the same region. Furthermore, it only applies to cases involving the death of several victims in the same incident, but the term "several" is not defined in the legislation. It is unclear whether the death of two victims in the same incident should

$21 \mathrm{n} 8,227$.

22 It should be noted that provincial judicial guidelines in the PRC are only highly persuasive to the local judges located in that province. They are not binding on the other courts in other provinces and regions of the PRC.

23 n 4. 
be covered by Article 17. Article 17 also states that a uniform approach may be adopted, which seems to suggest that this approach is not to be regarded as mandatory. However, it is unclear how (and under what circumstances) judges should exercise their discretionary power in a principled and non-arbitrary manner. ${ }^{24}$

The current problems associated with the urban-rural discrimination still remains unresolved in the PRC. The urban-rural income gap is very unlikely to be closed in the foreseeable future, owing to the current socioeconomic structure and development strategy. It is argued that the need to carry out legal reforms in this area is pressing.

\section{The Common Law Approach in the United Kingdom and Hong Kong}

In the UK, ${ }^{25}$ claimants in personal injury litigation may seek payment of damages as a lump sum instead of periodic payment orders. ${ }^{26}$ The main advantage of a lump sum payment is that the proceedings can be concluded with a clean break between the parties, i.e. once the damages are paid, the defendant is clear of any further responsibility. In calculating such lump sum payments, law courts often use a multiplier-multiplicand approach. The multiplicand represents the annual loss of earnings and other benefits as assessed at the trial date, and is established by evidence put before the judge. The multiplier discounts future pecuniary values into a single present-day lump sum amount, based on the time value of money and the expected mortality of the claimant. The total amount payable is simply the product of the multiplicand and the multiplier.

For many years, multipliers in the UK have been determined via an impressionistic approach based on a spread of multipliers in comparable cases. In 1984, the first edition of the "Actuarial Tables with Explanatory Notes for Use in Personal Injury and Fatal Accident Cases" was published. These tables are generally called the "Ogden Tables," after Sir Michael Ogden QC, who was responsible for their publication and was also the chairperson of the joint working

$24 \mathrm{n} 8,232$.

25 Part of the analysis of the common approach in the UK is based on the authors' previous articles, including W.S. Chan, F. Chan and J. Li, "A Threshold Formula for Indexing the Discount Rate for Actuarial assessment of Damages in Personal Injury Litigation," Journal of Personal Injury Law 139, (2010) 3; F. Chan, W.S. Chan and J. Li, "Actuarial assessment of damages in personal injury litigation: how precise are we?” Law Probability and Risk 25, (2012) 11.

26 For example, Love v Dewsbury [2010] EWHC 3452. 
party of actuaries and lawyers responsible for victim compensation. The tables contain actuarially calculated multipliers that are suitable for a variety of possible circumstances.

The Ogden Tables initially had no legal authority. Although they have been used extensively by judges as a starting point in the choice of multiplier, they received formal recognition only recently. Under the Civil Evidence Act 1995, the Ogden Tables became admissible as evidence in personal injury actions for assessing future pecuniary losses. In July 1998, the House of Lords made an innovative decision in Wells $v$. Wells. ${ }^{27}$ In that decision, the conventional approach was abandoned, and actuarial evidence was approved as the primary method of assessing future pecuniary loss rather than as a mere check. After continual revisions, the Ogden Tables are now in their seventh edition. ${ }^{28}$ The multipliers therein are based on projected future mortality rates taken from the 2008-based national population projections published by the UK Government Actuary's Department.

In deriving the Ogden Tables, the concept of actuarial (or expected) present values is used, which means that although claimants may live longer or die earlier than their life expectancies, departures from expected lifetimes cancel one another out. As a result, if a large pool of personal injury claimants is considered, then on average, a lump sum payment determined by the Ogden Tables would be just enough to cover a claimant's future loss of earnings and other benefits. In other words, the resulting lump sum payment can be viewed as fair to both parties in a personal injury trial. One should keep in mind, however, that the fairness of the actuarial approach holds if and only if the demographic and financial assumptions made in calculating the multiplier are correct. Two major assumptions underlie the Ogden Tables: (1) the claimant's survival probability distribution and (2) the risk-free rate of return (net of inflation). Both are difficult to estimate, and thus there is an enormous likelihood that the actual survival distribution and rate of return will turn out to be different from those assumed in the computation. From a risk management perspective, the risk arising from errors in these assumptions is systematic because it affects all claimants who rely on the same set of actuarial tables. For instance, a fixed rate of $2.5 \%$ per annum is presently used to discount future losses and expenses. ${ }^{29}$ If this rate is higher than the prevailing risk-free rate of return, then all compensations will be biased on

27 [1998] UKHL 27; [1999] 1 AC 345 (HL).

28 Robin De Wilde QC (ed), Facts and Figures 2014/15; Tables for the Calculation of Damages (Sweet and Maxwell, 2014).

29 Set by the Lord Chancellor under the Damages (Personal Injury) Order 2001, pursuant to s 1 of the Damages Act 1996. 
the low side. Currently, the UK government is conducting a public consultation regarding the fairness of the discount rate. ${ }^{30}$

Hong Kong adopts a common law system which is very similar to that of the UK. Hong Kong applies restitutio in integrum as the basic principle underlying the assessment of damages. ${ }^{31}$ This principle has been defined in various dicta of the common law courts. In the words of Lord Blackburn in Livingstone $v$ Rawyards Coal Co, "Where any injury is to be compensated by damages, in settling the sum of money to be given ....you should as nearly as possible get at that sum of money which will put the person who has been injured .... in the same position as he would have been in if he had not sustained the wrong (at 44)."

Conventionally, the Hong Kong courts follow the English authorities in awarding lump sum compensations using the multiplicand-multiplier approach. Most judges in the past have selected multipliers with reference to a spread of multipliers in comparable English and Hong Kong cases. The economic landscape and mortality patterns in Hong Kong have been changing rapidly during the past 50 years or so. It is practically impossible to find a truly comparable case with similar factors in respect of the gender and age of the victim, mortality experience of the general population, rates of inflation and investment return. Therefore, the fairness of conventional multipliers, which is based on analogy, is questionable. The conventional approach was first challenged in the Hong Kong Court of First Instance in 1995, in Chan Pui Ki (an infant) v Leung On. ${ }^{33}$ The trial judge abandoned the conventional method of choosing multipliers and admitted actuarial evidence to calculate the appropriate value. However, this decision was reversed by the Hong Kong Court of Appeal in 1996, ${ }^{34}$ which held that the conventional multipliers for the calculation of loss of future earnings should be maintained. In contrast, the House of Lords in England made a landmark decision in Wells $v$ Wells ${ }^{35}$ in 1998. It

30 The UK Ministry of Justice released two consultation papers on the discount rate: (1) "Damages Act 1996: The Discount Rate - How should it be set?” CP12/2012; and (2) “Damages Act 1996: The Discount Rate - Review of the Legal Framework" CP3/2013. The former UK Government Actuary Dr Chris Daykin believed that the rate should be reduced to $1.5 \%$ or even $1 \%$ : see C. Daykin, "Fair Compensation Needs Actuaries," Journal of Personal Injury Law 48, (2009) 16.

31 Part of the analysis of the common approach in the HK is based on the authors' previous works, including W.S. Chan, F. Chan and J. Li, Personal Injury Tables Hong Kong 2013: Tables for the Calculation of Damages (Sweet and Maxwell, 2013); F. Chan, W.S. Chan and J. Li, "Using Actuarial Evidence in Singapore and Hong Kong: A Sequel to Lai Wee Lian Revisited," Hong Kong Law Journal 45, no. 2 (2015), 499.

32 [1880] 5 App Case 25 (HL).

33 [1995] HKCFI 267; [1995] 3 HKC 732 (Hong Kong Court of First Instance).

34 [1996] HKCA 615; [1996] 2 HKC 565 (Hong Kong Court of Appeal).

$35 \mathrm{n} 26$. 
approved actuarial evidence (the Ogden Tables ${ }^{36}$ ) as the primary method of assessing future pecuniary loss.

Even though Article 8 of the Hong Kong Basic Law specifies that the common law previously in force in Hong Kong shall be maintained, judicial decisions in the UK may no longer be binding in the Hong Kong courts since the change of sovereignty in July 1997. The Hong Kong courts have continued to use the conventional approach to determine multipliers since the 1998 decision of Wells $v$ Wells in the UK. Even if the Hong Kong Courts were to follow the Wells $v$ Wells decision, it would not be practical for Hong Kong to simply adopt the Ogden Tables, as they were constructed in the light of circumstances in the UK, not those in Hong Kong. The mortality experience and the economic conditions in Hong Kong and the UK are very different and the Hong Kong specific actuarial tables were not generally available at that time.

Multiplier tables for Hong Kong have been published using a methodology analogous to that used for the formulation of the Ogden Tables in England. ${ }^{37}$ The Hong Kong courts have been slowly moving towards a standard method of assessing future loss by means of actuarial annuity tables. An important factor in determining personal injury damages is the net rate of return (i.e. the discount rate). The discount rate is the annual net rate of investment return in excess of inflation that the claimant is assumed to achieve on the lump-sum award. The lump sum (i.e. the capital) and the income streams generated from the capital should meet exactly the whole amount of the losses or costs (inflation-adjusted) as they arise during the entire future period. It is also assumed that nothing will be left by the end of the future period. The lower the assumed discount rate, the larger the multiplier and the resultant lump-sum award. The choice of discount rate could have a significant effect on the magnitude of the multiplier. For example, it was demonstrated in the UK that a young claimant could be under-compensated by more than $56 \%$ if the discount rate changed from the prescribed $2.5 \%-1 \%$ according to the prevailing market conditions. ${ }^{38}$

The discount rate depends significantly on the most appropriate investment strategy assumed by the court for the sake of protecting the claimant. The conventional discount rate in the UK before July 1998 was 4.5\% per annum, premised on the assumption that the claimant would invest the lump-sum award in a mixed portfolio of government bonds and shares. ${ }^{39}$ This was reduced to 3\% by the House

$36 \mathrm{n} 27$.

37 W.S. Chan, F. Chan and J. Li, Personal Injury Tables Hong Kong 2013: Tables for the Calculation of Damages (Sweet and Maxwell, 2013).

38 Robin de Wilde (ed.), Facts \& Figures 2008/09: Tables for the Calculation of Damages (Sweet and Maxwell, 2008), xi.

39 Cookson v Knowles [1979] AC 556 (HL). 
of Lords in Wells $v$ Wells on the basis that a claimant should not be expected to invest his damages in "risky" investments. The rate was further reduced to $2.5 \%$ in $2001^{40}$ and has since remained unchanged. ${ }^{41}$ However, developments in the UK concerning the setting of the discount rate went unheeded by the Hong Kong Courts. The $4.5 \%$ conventional discount rate continued to be applied in Hong Kong, until two significant decisions were recently made by Justice Bharwaney in Chan Pak Ting (No. 1) ${ }^{42}$ and Chan Pak Ting (No. 2). ${ }^{43}$ Chan Pak Ting, 31 years old at the date of the trial, suffered catastrophic injuries after a car crash. Two clinical negligence cases were consolidated together with Chan Pak Ting on the same issues related to actuarial tables and discount rates. The plaintiffs were 12-year old $\mathrm{Li} \mathrm{Ka}$ Wai, who suffered from deprivation of oxygen at birth and became paraplegic, and 12-year old Yuen Hiu Tung, who suffered a cardio-respiratory seizure and became mentally retarded and paralysed. As discussed, the Ogden Tables were approved by the House of Lords as the primary method of assessing future pecuniary loss in personal injury claims, rather than as a mere check (Wells $v$ Wells $\left.{ }^{44}\right)$. The Personal Injury Tables Hong Kong 2013: Tables for the Calculation of Damages $^{45}$ gained judicial recognition in Chan Pak Ting (No. 1). Bharwaney stated that "[32] ... I agree that the [Actuarial] Tables should be accepted as the starting point in Hong Kong, just as the Ogden Tables are accepted as the starting point in the UK. In future, there should be less need to refer to previous case law of multiplier precedents, particularly if those cases were decided without reference to actuarial tables by way of a cross-check."

In Chan Pak Ting (No. 2), Bharwaney departed from the conventional discount rate of $4.5 \%$ per annum (set by the House of Lords in Cookson v Knowles; ${ }^{46}$ endorsed by the Hong Kong Court of Appeal in Chan Pui $\mathrm{Ki}^{47}$ ). Having examined Hong Kong's economic evidence, he set three different discount rates, reflecting the investment choices of each class of investors as driven by their specific needs and goals. For needs exceeding 10 years, he set a discount rate of $2.5 \%$ per annum by taking an

40 The Lord Chancellor at that time exercised his power pursuant to s 1 of the Damages Act 1996 in England to reduce the rate.

41 Yet, for the past 15 years, the UK government interest yields have been sliding down and significantly below that rate. The UK Government has been under tremendous pressure to review the rate. See R Edwards, “The Discount Rate: Seeking to Square the Circle,” Solicitors Journal (18 January 2013).

42 [2012] HKCFI 1584; [2013] 2 HKC 182 (Hong Kong Court of First Instance).

43 [2013] HKCFI 179; [2013] 2 HKC 365 (Hong Kong Court of First Instance).

$44 \mathrm{n} 26$.

$45 \mathrm{n} 36$.

46 [1979] AC 556 (HL).

47 [1996] 2 HKC 565 (Hong Kong Court of Appeal). 
"average" portfolio of (1) 10\% in time deposits; (2) 70\% in high quality bonds; and (3) 20\% in high quality blue-chips, which qualify as "widows and orphans" stock. It should be noted that $2.5 \%$ is also the current discount rate in the UK. ${ }^{48}$ For needs extending beyond 5 years but not exceeding 10 years, the court set a discount rate of $1 \%$ per annum. ${ }^{49}$ For needs not exceeding 5 years, a negative discount rate of $-0.5 \%$ per annum ${ }^{50}$ was set, following the Privy Council's decision in Simon $v$ Helmot $^{51}$ that there was nothing wrong in principle in setting a negative discount rate. Lord Hope of the Privy Council in Simon v Helmot noted that in Guernsey, there was a significant difference $(2 \%)$ between price inflation (concerning future expenses) and wage inflation (for loss of earnings until retirement age). ${ }^{52}$ To reflect the disparity, he adopted $0.5 \%$ as the discount rate for non-earnings related losses and $-1.5 \%$ for earnings-related losses, to reflect the fact that wage inflation was substantially higher than price inflation..$^{53}$ In Chan Pak Ting, the economic data for Hong Kong show that the difference between price inflation and wage inflation (from 2001 to 2012) was only $0.4 \%$, which was not substantial enough to justify separate discount rates for earnings-related and non-earnings related losses. The Personal Injury Tables Hong Kong have been cited a number of times in the Hong Kong courts since Chan Pak Ting. ${ }^{54}$ Choosing multipliers "intuitively" on impressionistic grounds (by reference to a spread of multipliers in comparable cases) has been eschewed. The breadth of factors that actuaries took into account when producing the actuarial tables is now fully appreciated.

\section{Comparative Analysis}

As examined above, the common law system in the UK and Hong Kong is remarkably different from the civil law system in the PRC, yet both legal systems often

\section{8 n 39.}

49 15\% in time deposits and 85\% in Hong Kong Government Exchange Fund Notes and high quality bonds.

50 20\% in time deposits and 80\% in HK Government Exchange Fund Notes.

51 [2012] UKPC 5, an appeal from the Guernsey Court of Appeal.

52 See $n$ 51, [30]-[36] (Lord Hope) regarding the actuarial evidence.

53 The gap of $2 \%$ represents the difference between $+0.5 \%$ and $-1.5 \%$.

54 A recent citation can be found in Chan Wai Ming $v$ Leung Shing Wah [2014] HKCA 318 (Hong Kong Court of Appeal). Justice Cheung of the Hong Kong Court of Appeal averred (at [8.5]): "In my view to hold on to the conventional multiplier approach which is based on the discount rate of $4.5-5 \%$ fails to provide full compensation to the victim because this notional return does not accord with the economic reality of present day Hong Kong. For my part, I would respectfully ... adopt the new approach." 
use the multiplicand-multiplier approach in assessing future loss. The objective is to calculate a lump sum to compensate the plaintiff for future loss of earnings, and future medical expenses for life. The lump sum is computed as the product of a multiplicand and a multiplier.

Under the common law system, the principle of meritocracy is invoked for determining the multiplicand. Meritocracy broadly refers to the process of making a judgement in accordance with people's various “demonstrated merits," including occupational achievement, educational background and professional attainment..$^{55}$ It is an evidence-oriented approach, and the multiplicand is determined on a case-by-case basis. For example, in a Hong Kong case, Chan Pui Ki (an infant) $v$ Leung $O n,{ }^{56}$ the trial judge had to examine the family background of a victim (who was only an infant when she was knocked down by a doubledecker bus) and her school reports. It was concluded that "it is highly probably that she would have earned above average earnings if not for the accident." As for the determination of the multiplier, both the UK and Hong Kong now adopt the actuarial tables as the starting point. The trial judge, based on the evidence concerning the claimant's personal circumstances (e.g. gender, expected retirement age, etc.), selects the appropriate multiplier from the actuarial tables under a determined discount rate that reflects the economic reality, and then makes the necessary adjustment (if any) to the actuarial multiplier to take into account of other risks and vicissitudes of life, such as that the claimant would, for periods, have ceased to earn due to ill health or loss of employment. This approach is consistent with the principle of meritocracy.

In contrast, the civil law system tends to adopt an egalitarian approach in the assessment of compensation for personal injury litigation. Egalitarianism can be defined as follows: "People should be treated as equals, should treat one another as equals, should relate as equals, or enjoy an equality of social status of some sort. Egalitarian doctrines tend to rest on a background idea that all human persons are equal in fundamental worth or moral status." 57

The multiplicands in the PRC are based on the average earnings in the same cohort of individuals. They do not take into account the possible individual differences of the claimants within the same cohort. However, under the current regulation (i.e. the PRC Judicial Interpretation, as explained above), the multiplicands are not entirely determined under an egalitarian approach because each

55 Michael Young, The Rise of the Meritocracy, 1870-2033: An Essay on Education and Inequality (Thames \& Hudson, 1958).

56 [1995] 3 HKC 732, at [150].

57 Richard Arneson, "Egalitarianism” Stanford Encyclopedia of Philosophy (Summer Edn 2013) <http://plato.stanford.edu/entries/egalitarianism/> accessed 15 October 2015. 
claimant is assigned to a pre-specified geographic region (e.g. urban versus rural) based on his/her status as determined by birth registration. As demonstrated in the earlier analysis, regional average earnings vary substantially. The use of a single national average level of earnings (instead of various provincial average earnings) without the urban-rural distinction appears to be a more ideal way of putting the egalitarian approach into judicial practise. However, given the current problems of income inequality and the huge urban-rural income gap in mainland China, ${ }^{58}$ this direction of reform may generate a great deal of controversy, and will not easily become a reality.

The determination of multipliers ${ }^{59}$ in the PRC is solely dependent on the age of the claimant, according to the egalitarian principle that people in the same age group should be treated equally by invoking the same multiplier regardless of their health conditions and socio-economic states. It must be emphasised that the function of the multiplier is to discount the future pecuniary values into a present-day lump-sum amount. The multipliers should therefore be constructed on the basis of national population and mortality statistics. For example, in Japan (a civil law jurisdiction), the multipliers are regularly updated and published in the public domain..$^{60}$ The multipliers stipulated in the PRC Judicial Interpretation (listed in Table 2) do not appear to have been prepared on a scientific basis. A probable explanation is that insufficient mortality statistics were available in the PRC when the tables were prepared. Adopting a similar methodology to that applied in constructing the Hong Kong multiplier tables, the present authors computed a set of multipliers for the PRC by making full use of the most recent PRC population data. Figure 3 compares the resulting multipliers (for males and females) with the current PRC multipliers. The computed multipliers are generally higher than those formulated in the Judicial Interpretation, especially for younger claimants. It is therefore logical to posit that personal injury compensation in the PRC is being unduly suppressed (especially for younger victims), leading to under-compensation of the victims. The legislature and the judiciary of the PRC should seriously consider re-examining the multipliers prescribed in the relevant legislation and the Judicial Interpretation, and the mechanism by which the rules are applied judicially in assessing the quantum of damages.

58 X. Yu and X. Zhou, "Income Inequality in Today’s China," Proceedings of the National Academy of Sciences of the United States of America 111, no. 19, (2014), 6928.

59 Table 2 above.

60 See various tables shown in the website of General Insurance Rating Organisation of Japan: $<$ http://www.giroj.or.jp/service/jibaiseki/shiharai/list.html\#shuurou_leibniz> accessed 15 October 2015. 


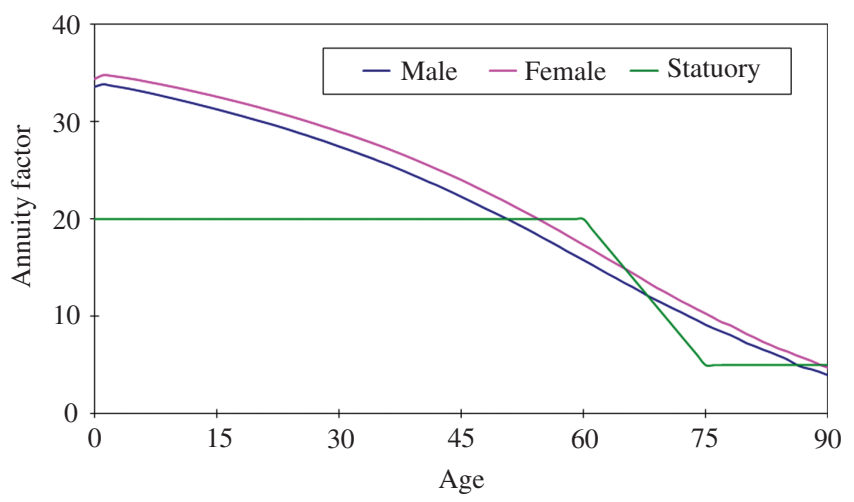

Figure 3: Actuarial Multipliers and Statutory Annuity Factors in the PRC (Source: China Statistical Yearbook, 2014).

\section{Conclusion}

The objective of personal injury compensation is to restore the victim, as far as practically possible, to the position in which he would have been had he not sustained the wrong. The moral objective underlying this supposition is intuitively appealing. It is not surprising, therefore, that this jurisprudential notion has been favourably received and widely applied in various common law and civil jurisdictions, despite differences in tradition and culture. The mechanism for assessing future losses of earnings must be based on justifiable economic factors that can be objectively valuated. Although it is impractical to expect the court to achieve mathematical certainty, it must make the best estimate it can. To achieve this goal, the court should use criteria such as life expectancy figures that reflect the proper and true value of money.

In this article, it is demonstrated that even though the PRC civil law and the English and Hong Kong common law share a similar objective in this arena, there are a number of differences in the substantive content of the law and the configuration of the rules. The authors argue, and provide empirical evidence to support, that there are signs of convergence. Both legal systems are in fact applying the same multiplicand-multiplier approach in assessing the quantum of damages. Case studies in mainland China (concerning civil law), the UK and Hong Kong (regarding common law) were adopted as the research methodology to explore the broader implications for such convergence. It is observed that due to the communist ideology in mainland China, the multiplicand cannot be determined on an individual basis by considering the evidence relating to a claimant's occupational achievement and educational attainment. Nonetheless, it does not mean 
that legal reform cannot be carried out in respect of the determination of multipliers in the PRC. It is demonstrated in this article that a more scientific methodology can be applied in constructing a set of actuarial multipliers for use in the PRC, by referring to the latest mortality and population statistics officially promulgated by the National Bureau of Statistics of China. ${ }^{61}$ There are legitimate reasons for concern that younger victims in the PRC are suffering from serious under-compensation due to the unjustifiable suppression of the multipliers for claimants at younger ages. It is hoped that the reform proposed in this article, if implemented, would achieve the goal of justice by effectively rectifying the deficiencies of the PRC tort system. After all, how a legal system responds to the needs of vulnerable victims of personal injury is arguably one of the most fundamental parameters for judging its level of morality and civilization.

Acknowledgments: This research project is supported by a grant from the Research Grants Council of the Hong Kong Special Administrative Region. (Project no. HKU741512H). 
Reproduced with permission of copyright owner. Further

reproduction prohibited without permission. 